\title{
First Report of Deep Crypt Secretory Cells in Ascending Colon in Chinchilla (Chinchilla lanigera): A Histological and Histochemical Study
}

\author{
Primer Reporte de Células Secretoras de Criptas Profundas en Colon Ascendente \\ en Chinchilla (Chinchilla lanigera): Un Estudio Histológico e Histoquímico
}

\author{
Ghiurco Florin $^{1}$; Damian Aurel ${ }^{1}$; Martonos Cristian ${ }^{1}$; Matei Maria-Catalina ${ }^{2}$; \\ Latiu Calin ${ }^{3}$; Rus Vasile ${ }^{4}$; Miclaus Viorel ${ }^{4}$ \& Gal Adrian Florin ${ }^{4}$
}

GHIURCO, F.; DAMiAn, A.; MARTONOS, C.; MATEI, M. C.; LATIU, C.; RUS, V.; MICLAUS, V. \& GAL, A. F. First reportof deep crypt secretory cells in ascending colon in chinchilla (Chinchilla lanigera): A histological and histochemical study. Int. J. Morphol., 39(4):1001-1005, 2021.

SUMMARY: The normal morphology of the colon differs among mammal species. The ascending colon presents several types of cells, responsible for carrying different functions for this organ. Among them, the mucus-secreting cells ensure the integrity of the mucosa, local defense, protection against different external factors, inflammatory diseases, cancer, etc. The ascending colon from 5 adult male chinchillas were processed for paraffin embedding and stained with three methods: Goldner's trichrome, PAS reaction, and Alcian blue staining procedure. The results showed that the structure of the ascending colon is similar to the one described in other species, i.e. mucosa, submucosa, muscularis externa, and serosa. Regarding the mucus-secreting cells present in the deeper part of the mucosal crypts (deep crypt secretory or DCS cells) turned out to be different not only morphologically from the surface goblet cells but also regarding the type of mucus synthesized. DCS cells have a multivacuolated, faintly stained cytoplasm with moderately PAS-positive reaction and intensely positive reaction to Alcian blue stain. The mean surface of DCS cells was $521.6 \mu \mathrm{m}^{2}$ as compared to $437.9 \mu \mathrm{m}^{2}$ for goblet cells (p<0.05). In conclusion, our study describes for the first time in chinchilla (Chinchilla lanigera) the presence of formerly known non-goblet or vacuolated cells, and recently entitled DCS cells in the glandular epithelium of the colon. The understanding of morphological peculiarities in chinchilla may serve as a good basis to understand the pathophysiology of various conditions that may arise.

KEY WORDS: Chinchilla; Colon; DCS cells; Goblet cell; Mucous substances.

\section{INTRODUCTION}

The intestinal epithelium has a protective role, it is capable of secreting or absorbing different substances, and even adapting to different diets or environmental conditions (Jaladanki \& Wang, 2016).The epithelium is usually divided into surface and glandular, which is actually the invagination of the surface epithelium in order to increase the surface area (Moyer, 2012). Its different segments contain specialized cells, usually renewing in a short period of time, but not all of them have the same turnover rate (Kim \& Ho, 2010). Knowing the cell types present in the intestine is crucial in better understanding how to feed the species, adapt the diet, or even comprehend the pathogenesis of colon conditions that arise in chinchilla. Moreover, the mucus layer on the surface of the epithelium participates in the local defense and is mainly secreted by goblet cells (Kim \& Ho). The integrity of the intestinal mucosa depends largely on the surface mucus layer among others (intercellular junctions, epithelial cells, host immune response) (Liévin-Le Moal \& Servin, 2006; Dharmani et al., 2009).

\footnotetext{
${ }^{1}$ University of Agricultural Sciences and Veterinary Medicine Cluj-Napoca, Faculty of Veterinary Medicine, Department of Anatomy, Manastur Street no 3-5, Cluj-Napoca, 400372, Romania.

${ }^{2}$ University of Agricultural Sciences and Veterinary Medicine Cluj-Napoca, Faculty of Veterinary Medicine, Department of Physiology, Manastur Street no 3-5, Cluj-Napoca, 400372, Romania.

${ }^{3}$ University of Agricultural Sciences and Veterinary Medicine Cluj-Napoca, Faculty of Animal Sciences, Manastur Street no 3-5, Cluj-Napoca, 400372, Romania.

${ }^{4}$ University of Agricultural Sciences and Veterinary Medicine Cluj-Napoca, Faculty of Veterinary Medicine, Department of Histology, Manastur Street no 3-5, Cluj-Napoca, 400372, Romania.
} 
GHIURCO, F.; DAMIAN, A.; MARTONOS, C.; MATEI, M. C.; LATIU, C.; RUS, V.; MICLAUS, V. \& GAL, A. F. First reportof deep crypt secretory cells in ascending colon in chinchilla (Chinchilla lanigera): A histological and histochemical study. Int. J. Morphol., 39(4):xxx-xxx, 2021.

The colon in humans is described to have the following types of cells: absorptive cells, goblet cells, undifferentiated columnar crypt cells, caveolated cells, Paneth cells and $M$ cells, all believed to arise from undifferentiated crypt cells (Jaladanki \& Wang). Various species of mammals have different cell populations, some authors reporting the presence of at least five types of cells (vacuolated, columnar, enteroendocrine, caveolated, and goblet) (Altmann, 1983). In rats, Karam (1999) described the following types of cells lining the ascending colon: vacuolated-columnar, goblet, enteroendocrine, vacuolated cells and a specific type present only here: deep crypt secretory (DCS) cells, at the crypt base. He mentions the presence of vacuolated-columnar and goblet cells in the superficial area of the crypt, precursor cells in the mid crypt and DCS cells in the crypt base. This means that the stem cells are the same for the three types of mentioned cells, but during differentiation, the columnar and goblet cells migrate towards the superficial part, whereas the DCS cells migrate inwards, toward the crypt base. These cells differentiate morphologically, but also functionally. Researchers describe the presence of socalled deep crypt secretory cells in the ascending colon, which secrete mucus. They renew every 14-21 days and migrate inwards (Karam). Other authors also describe the presence of mucus-secreting cells in the deep crypts of the ascending colon in rats, specifying they are nongoblet (Altmann, 1983). In fact, the first description of so-called vacuolated cells was performed by Hollman (1965) in the rectum of humans, rabbits, and rats. Later, these cells were named nongoblet, deep crypt mucous, and in the last years, deep crypt secretory (DCS) cells (Altmann, 1983).

The normal morphology of the colon differs among mammal species, thus breeders, researchers, and clinicians should have a rich database to be able to be fully informed before working with chinchillas. We aimed to describe the colon wall in chinchillas and also characterize the mucus-secreting cells on special staining procedures.

\section{MATERIAL AND METHOD}

Study population. The biological material was represented by 5 adult chinchillas (Chinchilla lanigera), brought shortly after their death for a complete necropsy examination to the Department of Necropsy, Faculty of Veterinary Medicine (University of Agricultural Sciences and Veterinary Medicine Cluj-Napoca, Romania). The assessment of all chinchillas showed that the natural cause of death was lobar pneumonia.
Study design and histological assessment. Colon samples were harvested, fixed in $10 \%$ buffered formalin, and subsequently processed for paraffin embedding. The tissue blocks were sectioned at $5 \mathrm{~mm}$ using a Leica rotary microtome (model RM2125, Nussloch, Germany) and Goldner's trichrome staining procedure was applied. Moreover, we utilized two other techniques: PAS (periodic acid-Schiff) reaction and Alcian blue stain, to identify and characterize the presence of mucous substances. The techniques used by us identify the carbohydrate groups, allowing a simpler classification into neutral or acid mucous substances. PAS reaction, on one hand, identifies the neutral mucous substances, while the Alcian blue stain $(\mathrm{pH} 2.5)$ identifies both non-sulfated and sulfated acid mucous substances (Kiernan, 1999). The slides were examined under an Olympus BX41 light microscope (Tokyo, Japan) and the achieved images were captured with an Olympus E-330 photo camera.

Cell morphology assessment. From the best-fit intercepted by histological sections of Lieberkühn glands, all cells were counted and identified on PAS staining images. After the counting, cells were grouped into three categories in an Excel sheet: DCS, Goblet cells, and other types of cells. The surfaces of DCS and Goblet cells were measured using Toupview (Amscope) software to the nearest $1 \mathrm{~mm}$.

Statistical analysis. To compare and analyze the mean surface size of DCS cells and Goblet cells, descriptive statistics and t-test (unpaired, two-tailed) were performed using GraphPad 8 software. Statistically significant values were considered $\mathrm{p}<0.05$.

\section{RESULTS}

The colon in the chinchilla resembles the one described in other mammals as a general aspect (Fig. 1A). The mucosa comprises the epithelium, lamina propria, and muscularis mucosae. The intestinal epithelium is simple columnar and the mucosa present from place to place infolds that form the intestinal crypts (Lieberkühn glands). The characteristic aspect of these glands is the fact that besides the enterocytes and goblet cells, easily noticed on the histological slides, they contain another category of cells, grouped in the lower third of the glands (Fig. 1B). Judging by their relatively foamy or multivacuolated faintly stained cytoplasm, they are mucus-secreting cells. Curiously, they are different from the classical goblet cells concerning their shape, i.e. cup-like appearance, but also the aspect of the cytoplasm, which allows us to state that 
GHIURCO, F.; DAMIAN, A.; MARTONOS, C.; MATEI, M. C.; LATIU, C.; RUS, V.; MICLAUS, V. \& GAL, A. F. First reportof deep crypt secretory cells in ascending colon in chinchilla (Chinchilla lanigera): A histological and histochemical study. Int. J. Morphol., 39(4):xxx-xxx, 2021.

these Lieberkühn glands contain two different types of mucous-synthesizing cells. Additionally, the nuclei of the multivacuolated deep-cryptmucous-synthesizing cells or also called DCS cells are basally located and oval, with the longer ax parallel with the subjacent basal membrane. As a comparison, the nuclei of the regular goblet cells have basally located, oval-shaped nuclei, with the longer ax perpendicular on the basal membrane (Fig. 1B-C).

Histochemically, the goblet cells from the colon in the chinchilla are intensely PAS-positive, whereas the multivacuolated (DCS) cells located in the deeper half of the intestinal glands displayed a moderately PAS-positive reaction (Fig. 1C). However, the Alcian blue reaction also revealed discreetly positive goblet cells and an intensely positive reaction to Alcian blue in multivacuolated (DCS) cells (Fig. 1D).
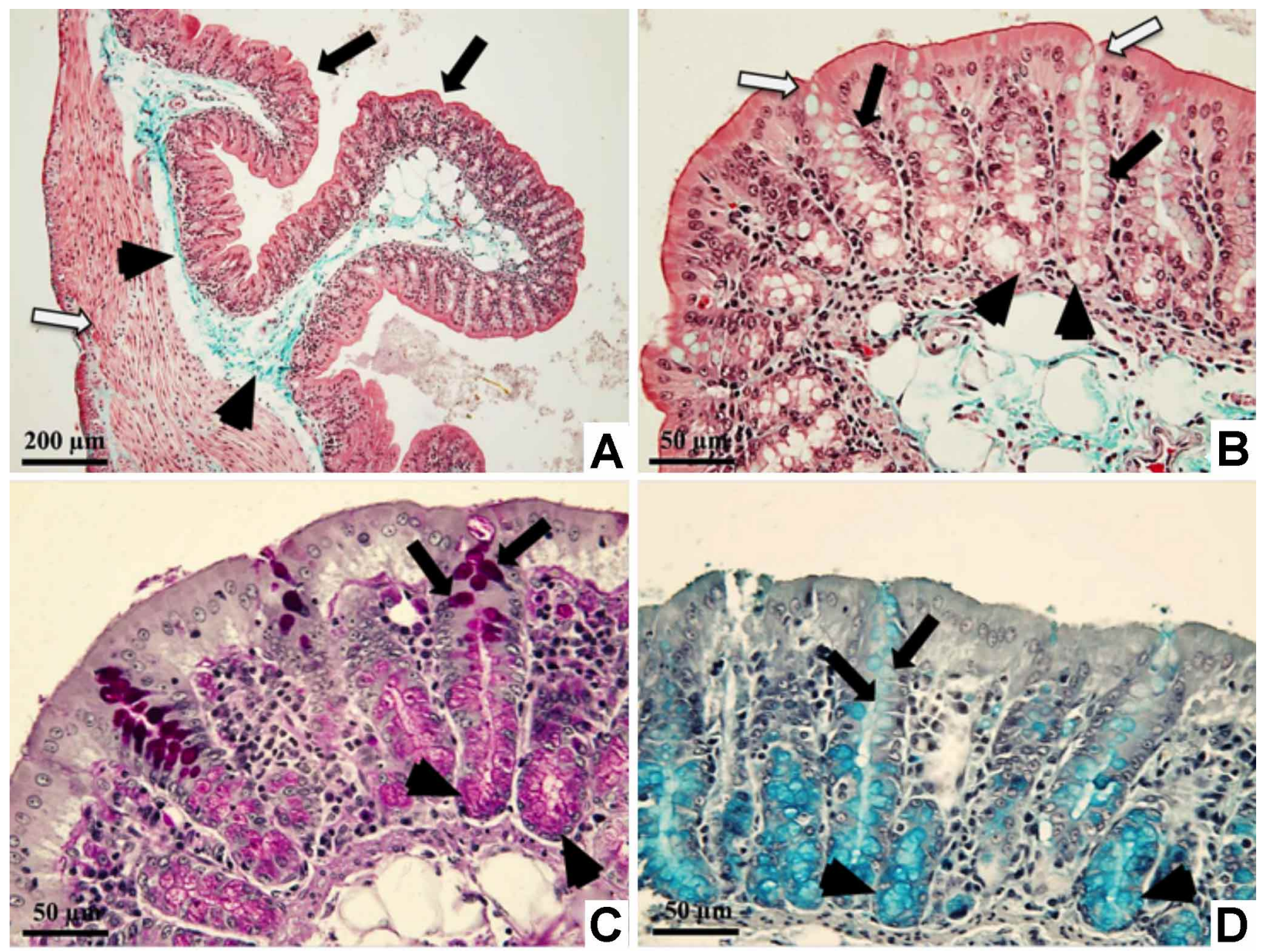

Fig. 1. A. Colon (Goldner's trichrome stain): black arrows -intestinal folds; white arrow - tunica muscularis externa; arrowheads - the submucosa.B. Colon (Goldner's trichrome stain): the presence of goblet cells with a cup-like appearance (black arrows) and multivacuolated DCS cells (arrowheads) in intestinal Lieberkühn glands (white arrows). C. Colon (PAS reaction): intensely PAS-positive goblet cells (black arrows) and moderately PAS-positive multivacuolated mucous-synthesizing cells (arrowheads). D. Colon (Alcian blue stain): moderately Alcian blue-positive goblet cells (black arrows) and intensely Alcian blue-positive DCS cells (arrowheads). 
Table I. Descriptive statistics of Goblet and DCS Cells measured surfaces and t-test.

\begin{tabular}{lccc}
\hline & Goblet Cells & DCS Cells & t-Test $\mathrm{p}<0.05$ \\
\hline Number of values & 50 & 50 & \\
Minimum $\left(\mu \mathrm{m}^{2}\right)$ & 161.1 & 195.5 & \\
Maximum $\left(\mu \mathrm{m}^{2}\right)$ & 823.1 & 958.4 & \\
Range $\left(\mu \mathrm{m}^{2}\right)$ & 662 & 762.9 & $*(\mathrm{p}$ value $=0.0274)$ \\
Mean $\left(\mu \mathrm{m}^{2}\right)$ & 437.9 & 521.6 & \\
Std. Deviation & 156.3 & 213.1 & \\
Std. Error of Mean & 22.1 & 30.14 & \\
Coefficient of variation & $35.68 \%$ & $40.85 \%$ & \\
\hline
\end{tabular}

*Statistically significant $(\mathrm{p}<0.05)$.

significant statistical differences between the mean values of surfaces of the two cell types $(p<0.05$; Table I). DCS cells are higher in numbers when compared to goblet cells and, at the same time, their surface is bigger (Fig. 2).

\section{DISCUSSION}

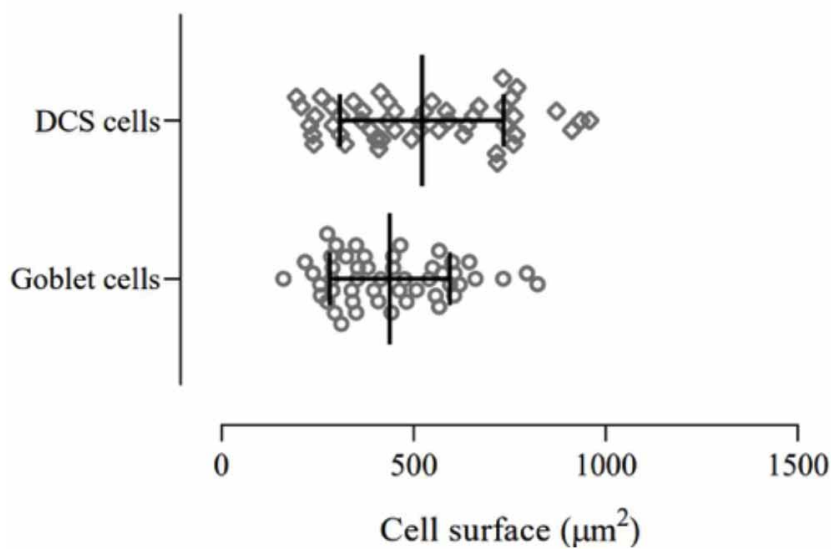

Fig. 2. Distribution, surface mean values, and standard deviation of DCS and goblet cells.

The DCS cells were reported to be different from goblet cells and were identified in a limited number of species (e.g., humans, rabbits, rats, mice). They produce glycoproteins and contain large quantities of Golgi complexes (Altmann, 1983; Kim \& Ho; Kober, 2013). Goblet cells are usually present in the surface epithelium and upper part of the intestinal crypts but are absent in the bottom part of the crypts where DCS cells are dominant. DCS cells are reported to have a different shape than goblet cells (i.e., multivacuolated cells vs cup-like appearance cells), being columnar, an aspect also observed by us. They derive from the same stem cells as the other types of cells, but they migrate to the base of the glands and differentiate into DCS cells. The mucus granules contained inside are reported to be large and light in mice, and rats, whereas in humans they appear rather small and dark (Altmann, 1990). In our study, the oval-shaped nucleus of DCS cells had a parallel orientation as compared to the subjacent basal membrane, whereas the goblet cells have an oval nucleus with a perpendicular alignment in relation to the basal membrane.

Upon histochemical examination, the results show that the Lieberkühn glands from the colon in the chinchilla present two different types of mucus-secreting cells. Accordingly, the goblet cells displayed an intensely PASpositive reaction and a discretely positive Alcian blue stain, while DCS cells showed a mild PAS-positive reaction and an intensely Alcian blue positive stain.The histochemical reactions of the above-mentioned mucussecreting cells suggest that they do not elaborate a similar type of mucus. Other authors also state that vacuolated cells contain more acidic mucin than goblet cells in rat ascending colon (Sakata \& von Engelhardt, 1981).

These features of the mucus-secreting cells of the Lieberkühn glands inthe colon were also observed in the large intestine of the grass cutter (Barnabas, 2016), humans, rats, and mice (Altmann, 1990). Given this particular situation, most probably, the role of the mucus secreted in this segment does not only imply lubricating the area (Sakata \& von Engelhardt).

Regarding the distribution of mucous non-goblet (DCS) cells in the intestinal mucosa, they were located almost exclusively in the deep one-half to one-third of the intestinal glands. A similar distribution was observed in the rat ascending colon (Sakata \& von Engelhardt). In rats, the PAS reaction was much more intense in goblet cells than in vacuolated ones, whereas the alcian blue stain was more intense in vacuolated cells than in the goblet ones. The results in the mouse colon showed that goblet cells had a more intense PAS-positive reaction than vacuolated ones, but the alcian blue stain was similar in intensity (Sakata \& von Engelhardt). Guinea pig investigations on the rat colon results showed that PAS reaction was more intensely positive in goblet cells than vacuolated ones. On the other hand, the alcian blue 
reaction was negative in goblet cells and positive in vacuolated ones (Sakata \& von Engelhardt).

Since goblet cells participate in microbial modulation (Deplancke \& Gaskins, 2001) it is important to know the types of cells secreting mucus to have an image about the capability of farm-raised chinchillas to defend against microorganisms or parasites (Kim \& Ho). The modification of mucus quantity and quality is also involved to some extent in cancer and inflammatory diseases of the intestines, but the matter remains to be further elucidated. If that is the case, the prevention or treatment of such disorders can be differently approached (Kim \& Ho).

In conclusion, the mucosa of the ascending colon in the chinchilla is similar histologically to the one described in other species, but the mucus-secreting cells have different trades depending on their location. The glandular epithelium contains goblet cells towards the superficial part and DCS cells in the deeper areas of the crypts, which are different both morphologically and histochemically. Our study describes for the first time in chinchilla (Chinchilla lanigera), the presence of formerly known non-goblet or vacuolated cells, and recently entitled DCS cells in the glandularepithelium of the colon. Finally, regardless of much progression in the latest years concerning the microanatomy in chinchilla (Chinchilla lanigera), the understanding of species peculiarities may serve as a good basis to understand the pathophysiology of various conditions that arise in chinchilla.

GHIURCO, F.; DAMIAN, A.; MARTONOS, C.; MATEI, M. C.; LATIU, C.; RUS, V.; MICLAUS, V. \& GAL, A. Primer reporte de células secretoras de criptas profundas en colon ascendente en chinchilla (Chinchilla lanigera): Un estudio histológico e histoquímico. Int. J. Morphol., 39(4):1001-1005, 2021.

RESUMEN: La morfología normal del colon es diferente entre las especies de mamíferos. El colon ascendente presenta varios tipos de células, encargadas de llevar varias funciones a este órgano. Entre ellos, las células secretoras aseguran la integridad de la mucosa, defensa local, protección frente a diferentes factores externos, enfermedades inflamatorias, cáncer, etc. Se procesaron para su inclusión en parafina el colon ascendente de 5 chinchillas machos adultos y se tiñeron con tres métodos: tricrómico de Goldner, reacción PAS y Azul de Alcian. Los resultados mostraron que la estructura de del colon ascendente es similar a la descrita en otras especies, es decir, mucosa, submucosa, muscular externa y serosa. Las células secretoras de la mucosa presente en la parte más profunda de las criptas mucosas (células secretoras de la cripta profunda o células DCS) resultaron ser diferentes morfológicamente de las células caliciformes superficiales, con citoplasma levemente teñido con reacción PAS positiva moderada y reacción intensamente positiva a Azul de Alcian. La superficie media de las células DCS fue de 521,6 $\mu \mathrm{m}^{2}$ en comparación con 437,9 $\mu \mathrm{m}^{2}$ de las células caliciformes ( $\mathrm{p}$ $<0,05)$. En conclusión, nuestro estudio describe por primera vez en chinchilla (Chinchilla lanigera) la presencia de células no caliciformes o vacuoladas anteriormente conocidas, y recientemente denominadas células DCS en el epitelio glandular del colon. La comprensión de las peculiaridades morfológicas de la chinchilla puede servir como una buena base para comprender la fisiopatología de las diversas afecciones.

PALABRAS CLAVE: Chinchilla; Colon; Células DCS; Célula caliciforme; Sustancias mucosas.

\section{REFERENCES}

Altmann, G. G. Morphological observations on mucus-secreting nongoblet cells in the deep crypts of the rat ascending colon. Am. J. Anat., 167(1):95117, 1983.

Altmann, G. G. Renewal of intestinal epithelium: New aspects as indicated by recent ultrastructural observations. J. Electron Microsc. Tech., 16(1):214, 1990.

Barnabas, K. K. Histological and Histochemical Studies of the Gastrointestinal Tract and Accessory Digestive Glands of the Grasscutter (Thryonomys swinderianus). Dissertation. Zaria, Nigeria, Ahmadu Bello University, Faculty of Medicine, 2016.

Deplancke, B. \& Gaskins, H. R. Microbial modulation of innate defense: goblet cells and the intestinal mucus layer. Am. J. Clin. Nutr., 73 (6):1131S-41S, 2001.

Dharmani, P.; Srivastava, V.; Kissoon-Singh, V. \& Chadee, K. Role of intestinal mucins in innate host defense mechanisms against pathogens. J. Innate Immun., 1(2):123-35, 2009.

Jaladanki, R. N. \& Wang, J. Y. Regulation of Gastrointestinal Mucosal Growth: Second Edition. Colloqium Series on Integrated Systems Physiology: From Molecule to Function. 8(4):1-132, 2016.

Karam, S. M. Lineage commitment and maturation of epithelial cells in the gut. Front. Biosci., 15 (4):D286-98, 1999.

Kiernan, J. A. Histological and Histochemical Methods: Theory and Practice. 3rd ed. Oxford, Butterworth Heinemann, 1999.

Kim, Y. S. \& Ho, S. B. Intestinal goblet cells and mucins in health and disease: Recent insights and progress. Curr. Gastroenterol. Rep.,12(5):319-30, 2010 .

Kober, O. The Role of Mucus in the Cross Talk Between Gut Bacteria and the Host. Norwich, Institute of Food Research Gut Health and Food Safety. Norwich Research Park Colney, 2013.

Liévin-Le Moal, V. \& Servin, A. L. The front line of enteric host defense against unwelcome intrusion of harmful microorganisms: mucins, antimicrobial peptides, and microbiota. Clin. Microbiol. Rev., 19(2):31537, 2006.

Moyer, M. Colon Cancer Cells. New York, Elsevier, 2012.

Sakata, T. \& von Engelhardt, W. Luminal mucin in the large intestine of mice, rats and guinea pigs. Cell Tissue Res., 219(3):629-35, 1981.

Corresponding author:

Matei Maria-Catalina

Manastur Street no 3-5

Cluj-Napoca, 400372

ROMANIA

E-mail: catalina.matei@usamvcluj.ro

Received: 02-04-2021

Accepted: 06-05-2021 